\title{
MIR21 Pre-miRNA
}

National Cancer Institute

\section{Source}

National Cancer Institute. MIR21 Pre-miRNA. NCI Thesaurus. Code C82714.

MIR21 pre-miRNA is an oligoribonucleotide that is encoded by the human MIR21 gene and is involved in the regulation of gene expression. 